Public Health Genomics. Author manuscript; available in PMC 2015 November 20.

Published in final edited form as:

Public Health Genomics. 2009 ; 12(5-6): 268-280. doi:10.1159/000214918.

\title{
Molecular Mechanisms of Human Papillomavirus-Induced Carcinogenesis
}

\author{
Michaël Lehoux, Claudia M. D’Abramo, and Jacques Archambault \\ Laboratory of Molecular Virology, Institut de Recherches Cliniques de Montréal, and Department \\ of Biochemistry, University of Montreal, Montreal, Que., Canada
}

\section{Abstract}

Approximately $20 \%$ of all cancers are associated with infectious agents. Among them, human papillomaviruses (HPVs) are very common and are now recognized as the etiological agent of cervical cancer, the second most common cancer in women worldwide, and they are increasingly linked with other forms of dysplasia. Carcinogenesis is a complex and multistep process requiring the acquisition of several genetic and/or epigenetic alterations. HPV-induced neoplasia, however, is in part mediated by the intrinsic functions of the viral proteins. In order to replicate its genome, HPV modulates the cell cycle, while deploying mechanisms to escape the host immune response, cellular senescence and apoptosis. As such, HPV infection leads directly and indirectly to genomic instability, further favouring transforming genetic events and progression to malignancy. This review aims to summarize our current understanding of the molecular mechanisms exploited by HPV to induce neoplasia, with an emphasis on the role of the 2 viral oncoproteins E6 and E7. Greater understanding of the role of HPV proteins in these processes will ultimately aid in the development of antiviral therapies, as well as unravel general mechanisms of oncogenesis.

\section{Keywords}

Human papillomavirus; Cervical cancer; Genomic instability; Oncogenesis; Viral oncogenes

\section{Introduction}

The notion that DNA tumor virus infections can trigger carcinogenesis originated many decades ago while examining malignant progression in domestic rabbits inoculated with wart-inducing viruses $[1,2]$. These oncogenic viral particles were later described as cottontail rabbit papillomaviruses and their human counterparts, human papillomaviruses (HPVs), were subsequently identified in human genital warts [3] and cervical biopsies [4]. Since then, infectious agents have been increasingly associated with cancer development, accounting for approximately $20 \%$ of cancers worldwide, with HPV responsible for nearly one third of them $[5,6]$.

Jacques Archambault, Laboratory of Molecular Virology, Institut de Recherches Cliniques de Montréal, 110 Pine Avenue West, Montreal, Que., H2W 1R7 (Canada), Tel. +1 514987 5739, Fax +1 514987 5741, jacques.archambault@ircm.qc.ca. 
The family of papillomaviruses comprises a plethora of different types that infect almost every vertebrate species, while showing a high species specificity [7, 8]. Over $100 \mathrm{HPV}$ types have been identified that infect either cutaneous or mucosal tissues [7], and among them, about 30-40 types infect the genital tract [9] and are presently recognized as the most common sexually transmitted infectious agents [10,11]. HPVs are commonly found in warts and anogenital dysplasias, although infections frequently remain subclinical. Anogenital HPVs are categorized as 'low-risk' or 'high-risk' types, according to their association with benign or pre-cancerous and cancerous lesions, respectively. The oncogenic potential of high-risk HPV types was initially demonstrated by Harald zur Hausen, who was recently awarded the 2008 Nobel Prize in Physiology or Medicine for this discovery [12]. High-risk HPVs are now recognized as the etiological agents of cervical cancer [13]. The burden of HPV-associated malignancies worldwide is enormous with 493,000 new cases of cervical cancer diagnosed each year, making it the second most common cancer in women [14, 15]. The incidence in developed countries has drastically declined with the implementation of Papanicolaou screening programs, such that approximately $80 \%$ of all new cases now occur in developing countries, where cervical cancer prevention programs are not available.

Nevertheless, 11,070 new cervical cancer cases were diagnosed in the United States in 2008, with a mortality rate of nearly 35\% [16]. HPVs 16 and 18 account for approximately $70 \%$ of all these cancers [17]. High-risk HPV types, in particular HPV-16, have also been identified in anal and other genital neoplasia and are associated with a subset of head and neck cancers [18-21]. This review will focus on the molecular events triggered by HPV infections that contribute to carcinogenesis.

\section{Epidemiology and Clinical Aspects}

Mucosal HPV types can infect epithelia of the anogenital and upper aerodigestive tract. Although HPV infections are very common, most remain asymptomatic and are cleared within 6-12 months through an effective immune response [22]. Nonetheless, a small subset of infections ultimately results in neoplasia. The link between HPV infections and cervical cancer is now strongly established, such that HPV is detected in $99.7 \%$ of cases [23] and in the vast majority of high-grade neoplasia [24]. HPV infections have also been associated with anal carcinogenesis and HPV is found in $80 \%$ of anal cancers, with HPV16 accounting for the majority of cases [25-27]. The occurrence of anal cancers has steadily increased since the 1980s, particularly in the HIV-positive population of men who have sex with men $[16,27,28]$. This has led to the suggestion that screening programs should be implemented within this population and other ones at a higher risk of developing anal dysplasia. Aside from their high susceptibility to anogenital cancers, HIV-positive and other immunosuppressed patients are at high risk of developing non-melanoma skin cancers when infected with HPV, especially at sun-exposed sites [29, 30]. Susceptibility to HPV-induced non-melanoma skin cancers upon UV exposure is also observed in the rare inherited disorder epidermodysplasia verruciformis [31]. Furthermore, HPV has been linked to other types of genital neoplasia, including vulvovaginal and penile cancers [27], and accumulating evidence suggests that HPV is associated with a subset of head and neck cancers, and in particular those of the tonsils. With the use of more sensitive viral DNA detection technologies, recent case-control studies proposed that HPV infection was causally 
associated with these cancers and was a risk factor independent from those previously reported, such as cigarette and alcohol consumption [18, 20, 21]. A systematic review of 60 different studies also confirmed a significantly higher prevalence of HPVs in these types of squamous-cell carcinomas [19].

Many factors contribute to the risk of HPV carcinogenesis including pregnancy, high parity, smoking, oral contraceptive use, other sexually transmitted diseases and the number of sexual partners [13]. Increasing evidence suggests that immunosuppressed patients also have a higher risk of carcinoma development and a higher prevalence of multiple HPV infections, as exemplified within the HIV-infected population and in organ transplant recipients [29, 32, 33]. Thus, the medical burden associated with HPV infections is substantial and may become even larger as these viruses are being linked to other malignancies.

\section{Overview of the Viral Life Cycle}

The molecular biology of HPV during its normal life cycle has been extensively reviewed $[17,34,35]$ and thus is only briefly summarized below. To initially infect dividing cells of the stratified epithelium, HPV virions are believed to reach the basal layer of the skin through microlesions. Mechanisms allowing entry from the extracellular milieu into the cell are poorly understood, but are known to proceed through interaction with cell surface heparan sulphate followed by clathrin- or caveola-mediated endocytosis [36, 37]. Then, translocation of the viral DNA into the nucleus involves the L2 capsid protein and is dependent on its interaction with microtubules [35, 38]. The viral genome consists of approximately $8 \mathrm{~kb}$ of circular double-stranded DNA and 8 well-defined open reading frames that are encoded in the early region (E1, E2, E4, E5, E6 and E7) and in the late region (L1 and L2). The genome also contains a third non-coding region, termed the long control region, that is critical for transcription of the viral genes, the initiation of viral DNA replication, and the segregation of the viral genome in mitosis (reviewed in [35]).

HPV relies extensively on host proteins for replication and maintenance of its genome. During a productive infection, the viral genome is maintained at a low copy number as an extrachromosomal element known as episome in the basal undifferentiated cells of the epithelium. Thereafter, the viral life cycle is tightly coupled to the differentiation program of keratinocytes and relies on several cellular factors and viral proteins. Normal epithelial cells undergo terminal differentiation as they migrate towards the upper layers, a condition that would be non-permissive for HPV replication since the virus depends on the host DNA replication machinery for replication of its genome. To maintain the cellular replication machinery active, the viral proteins E6 and E7 are expressed and uncouple cell growth arrest and differentiation primarily through the inactivation of p53 and pRb, respectively. At the core of these events are the facts that inactivation of pRb by E7 forces infected cells to remain in a proliferative state and escape cell cycle exit, while abrogation of p53 by E6 ensures cell survival by preventing apoptosis triggered by this aberrant growth signal. Viral genome replication requires the viral initiator protein E1, which contains a helicase-ATPase activity, and the multifunctional viral protein E2, which helps in the specific recruitment of E1 to the viral DNA. E1 oligomerizes and assembles as a double-hexamer at the viral origin of DNA replication and functionally interacts with several host replication factors, such as 
polymerase a-primase, replication protein A, topoisomerase I and cyclin E/Cdk2 [35, 39]. E2 also functions as a transcription factor, capable of trans-activation and repression [40, 41], and as a mediator of genome segregation, which is essential for viral persistence [42, 43]. As the infected cells undergo differentiation, late gene expression and viral genome replication are induced (fig. 1). The amplified genomes are then packaged into infectious virions by the L1 and L2 proteins, which form the subunits of the icosahedral capsid. Finally, viral egress probably occurs by natural tissue desquamation and may be facilitated by the keratin network disrupting ability of E4 [34]. E4 and E5 are both required for viral amplification, although their exact functions in this process are not clearly defined [44-46].

\section{Viral Genome Integration and Oncoprotein Expression}

The preceding section described the molecular events involved in the normal life cycle of HPV, during which the viral genome is always maintained in episomal form. However, in the majority of high-grade cervical lesions and cancers, the viral DNA is not found as an extrachromosomal element but rather is integrated into the host genomic DNA [34, 35, 47]. This rare and aberrant integration event greatly facilitates tumorigenesis and appears to seldom involve disruption of cellular transcribed sequences [48, 49], although it has been suggested to occasionally affect certain tumor suppressor genes [50-53]. HPV integration contributes to oncogenesis mainly when it involves disruption of the E2 open reading frame [54]. Aside from its essential role in viral replication, E2 also functions as a transcriptional repressor of the viral oncogenes, E6 and E7. As such, HPV integration events that disrupt E2 expression result in increased expression of the viral oncoproteins which, in turn, promotes cellular immortalization and transformation $[55,56]$. The expression of E6 and E7 alone has been shown to immortalize cultured human foreskin keratinocytes in a cooperative manner [57, 58]. Moreover, continued expression of E6 and E7 is essential to maintain cervical carcinoma cells in a transformed state, as illustrated by the fact that restoring E2 expression in cervical cancer cell lines represses E6 and E7 expression and induces cell cycle arrest and eventually senescence [59, 60]. Both E6 and E7 are tumorigenic when expressed separately or together in transgenic mice, but induce distinct malignancies [61, 62]. This can be explained by their different mechanism of transformation emphasizing their cooperative function in tumor development.

The oncogenic potential of HPV E7 was first demonstrated by its ability to immortalize rodent fibroblasts $[63,64]$. Subsequently, development of high-grade dysplasias was observed in transgenic mice expressing E7 [61, 65]. E7 consists of approximately 100 amino acids and contains regions of high-sequence homology to adenovirus E1A and SV40 large T antigen [66]. These domains are known to bind to the family of cellular 'pocket proteins' including pRb, p107 and p130 (fig. 2a) [35, 67]. Through these interactions, the viral oncogene E7 functions primarily to modulate the proliferation status of infected cells. Normal cells use the $\mathrm{pRb}$ family members to regulate the G1/S transition by constitutively sequestering the E2F family of transcription factors. For normal S-phase entry, pRb hyperphosphorylation is induced by the cell cycle regulators cyclin-dependent kinases (Cdks). This leads to the activation of E2F and the subsequent trans-activation of its target genes, which is essential for the expression of many proteins involved in S-phase, such as those needed for DNA replication. In HPV-infected cells, activation of the E2F transcription 
factors is brought about by E7, which directly binds to pRb (reviewed in [35] ). In high-risk HPVs, this interaction results in the proteasome-dependent degradation of $\mathrm{pRb}$, possibly through the recruitment of an E3-ubiquitin ligase that has yet to be identified [68, 69]. Some studies reported that the cullin 2 ubiquitin ligase complex is implicated in HPV-16 E7mediated $\mathrm{pRb}$ destabilization, but the conservation of this mechanism among HPV types is uncertain [70]. E7 induction of cellular proliferation is a critical step for tumorigenesis and depends on its capacity to bind and destabilize $\mathrm{pRb}[71,72]$.

Deregulated and sustained cellular proliferation signals often trigger cell growth arrest and apoptosis. This is also observed in E7-expressing cells, which undergo apoptosis in a p53dependent manner [72]. This is overcome by the expression of E6, the second viral oncoprotein, which specifically binds to and inactivates $\mathrm{p} 53$, preventing activation of its antiproliferative and pro-apoptotic target genes. High-risk E6 associates with the cellular E3 ubiquitin ligase E6-associated protein (E6-AP), the prototypical member of the HECT family (homologous to E6-AP C-terminus), to form a ternary complex with p53 [73]. E6-AP does not regulate p53 stability in non-infected cells [74], but, when in complex with E6, it strongly induces p53 poly-ubiquitination and its subsequent proteasomal degradation [75]. In vitro, E6 overexpression alone is sufficient to immortalize mammary epithelial cells [76], a process that requires E6-AP association and down-regulation of p53 [77, 78]. Nevertheless, even when the proteasome is inhibited, E6 still retains some p53-inhibitory functions, possibly by preventing its nuclear translocation [79] and/or by inhibiting its transcriptional coactivator $\mathrm{p} 300 / \mathrm{CBP}[80,81]$. Of interest is that the immortalizing potential of E6 is exclusive to high-risk HPV types, suggesting that intrinsic differences between proteins of low and high risk, as well as distinct features of high-risk E6, explain its oncogenic properties. It is known that E6 from different HPV types bind and inhibit p53 with variable potencies, and that only high-risk E6 is capable of mediating p53 degradation [82]. Interestingly, low-risk E6 proteins, such as the one from HPV-11, can associate with E6-AP, although they do not induce degradation of p53 [83]. This raises the possibility that low-risk E6 can promote the degradation of cellular substrates not yet identified. Another feature unique to the high-risk HPV types is a PDZ-binding domain at the C-terminal end $[\mathrm{x}(\mathrm{T} / \mathrm{S}) \mathrm{x}(\mathrm{V} / \mathrm{L})]$, which enables E6 to interact with a subset of PDZ domain-containing proteins including hDlg, hScribb, MUPP-1, PATJ, TIP-2/GIPC, PTPN13 and MAGIs 1, 2 and 3, to promote their proteasomal degradation (fig. 2b) [84-89]. E6 activities have also been investigated in transgenic mice models expressing wild-type or mutant forms of E6 [90]. These studies demonstrated that the E6 region implicated in p53 inactivation and the Cterminal PDZ-binding domain independently contribute to oncogenesis. Interestingly, splicing variants of E6 that retain the ability to interact with E6-AP but lack the PDZbinding domain are also expressed in vivo. These variants, globally referred to as E6*, inhibit p53 degradation induced by full-length E6 and thus may serve to negatively regulate the immortalizing activities of E6 [91].

To date, numerous interacting partners of E6 and E7 have been identified, several of which will be discussed in the subsequent sections. These proteins have not all been characterized to the same extent, such that the relevance of some of them to HPV infections and carcinogenesis still remains to be established. Nonetheless, it is clear that E6 and E7 overexpression alone is not sufficient to induce malignancy. For instance, E6 and E7 
immortalized human foreskin keratinocytes are not fully transformed and are unable to induce tumors when grafted into nude mice unless the cells are passaged several times to acquire additional genetic changes [92]. The same likely occurs in humans, such that most infections remain benign and transient, with regression occurring in the first 2 years, and persistent infection required for development of neoplasia [11]. Tumorigenesis is a multistep process necessitating the acquisition of several genetic alterations [93]. For example, mutations in the Ras oncogene have been detected in many high-grade and cancerous cervical lesions in humans [94, 95], suggesting that activating mutations in RAS may be one of these genetic modifications cooperating with HPV to promote carcinogenesis. In support of this, activated Ras was shown to cooperate with the 2 HPV oncogenes E6 and E7 in the transformation of rodent primary cells $[96,97]$. In normal cells, spontaneous mutations rarely occur, but HPV-infected cells exhibit a high genomic instability which is, in part, directly induced by viral proteins.

\section{Genomic Instability}

The low frequency of HPV-induced carcinogenesis and the fact that persistent HPV infection is required for neoplasia to occur underlines the need for additional cellular events for progression to malignancy. Cancer has often been described as a disease of genomic instability, particularly in epithelial cells [98]. Expression of E6 and E7 alone is sufficient to induce genomic instability and the accumulation of secondary mutations [99-101]. By doing so, E6 and E7 may facilitate viral genome integration [49] which in turn would result in their increased expression and further promote instability [102, 103]. This order of events is not perfectly understood. As such, an unintended consequence of integration is that it facilitates progression to malignancy (fig. 3). Through this phenomenon and in response to their environment, transforming cells are clonally selected in a Darwinian manner [93, 104]. Genomic instability is simultaneously caused by the E7-mediated activation of Cdk2 [105] and by the disruption of key cell cycle regulatory events such as the G1/S and mitotic checkpoints [106, 107].

Abrogation of the mitotic checkpoint promotes aneuploidy, a common feature of cancer cells which is characterized by an abnormal number of chromosomes (gain or loss) resulting from a non-symmetrical segregation of chromosomes during mitosis. Many studies reported this phenomenon in cells expressing E7 alone and have suggested that HPV-infected cells induce chromosomal aberrations, even in p53 unaltered cells [101, 108]. Aneuploidy can also be observed in early premalignant lesions and several recent studies have revealed that E7 induces centrosome abnormalities prior to genomic instability [109]. The implication of aneuploidy in tumorigenesis is highly controversial for it is currently unknown whether it is an inducer of transformation or the result of cellular deregulation. While this debate is beyond the scope of this paper, it is clear that HPV induces mitotic defects. Globally, E6 and E7 seem to possess intrinsic functions to induce genomic instability that are both independent and synergistic.

Like many other viral infections, HPV interacts with some DNA repair pathways [110]. It is suspected that DNA damage, as well as DNA virus infection and integration, lead to the activation of common cellular repair mechanisms. Consequently, a virus could benefit from 
interacting with the DNA repair machinery, both to inhibit its antiproliferative properties and to exploit some of its intrinsic abilities to mediate specific DNA transactions. This is exemplified by the recently identified relationship between HPV and the Fanconi anemia (FA) pathway. FA is a genetic disease characterized by a high genomic instability, which results in an increased susceptibility to bone marrow failure and cancers, such as squamous cell carcinomas (SCC) [111]. These pathological features are linked to defects in one of the 13 currently known FA genes ensuring genomic integrity [112]. Some studies suggested that squamous cell carcinoma in FA patients is tightly associated with HPV infection, making FA potentially the second inherited disease that increases susceptibility to HPV-induced carcinogenesis, in addition to epidermodysplasia verruciformis [113]. The link between the FA pathway and HPV infections also appear to hold true in non-FA patients, since some FA genes become epigenetically inactivated during cervical carcinogenesis [114]. Epigenetic silencing of tumor suppressor genes by promoter hypermethylation is also a common phenomenon in cervical carcinogenesis, along with mutations, deletions and chromosome translocations [115-117]. During early infection, the FA pathway may provide an early response mechanism to DNA perturbations induced by E6 and E7. Studies have shown that expression of E7 alone is sufficient to activate the FA pathway [118] and to induce expression of the downstream effector FANCD2 in a E2F-dependent manner [119]. Of interest, the FA pathway may regulate genomic integrity at common fragile sites, which are often the sites of HPV integration [118, 120,121]. Moreover, inactivation of FA genes represents an important molecular step for cancer progression. Many FA genes have been linked to chemotherapy resistance in multiple cancers [122], although whether this occurs in cervical cancer remains to be investigated. Although HPV infection exploits some functions of the DNA repair machinery, it also, by its association with genetic and epigenetic events, represses these pathways, thereby promoting the increased genomic plasticity required for cancer progression.

\section{Limitless and Sustained Growth}

Cancerous cells lose their potential to regulate the cell cycle and undergo uncontrolled growth. It is not surprising that HPV contributes directly to cellular transformation by stimulating unrestrained cell division and removing the requirement for mitogenic growth signals. The oncoprotein E7 is the major protein contributing to cell proliferation in HPV infection. Aside from its central role in inactivating $\mathrm{pRb}$ and related pocket proteins to promote transcription of E2F target genes, recent research has unravelled some new functions of E7 in cellular transformation. E7 not only indirectly induces Cdk2 expression by inhibiting $\mathrm{pRb}$, but also binds and activates $\mathrm{Cdk} 2$ directly while in complex with either cyclin A or E [123]. E7 also counteracts the effect of the Cdk inhibitors p21 [124, 125] and p27 [126] by directly binding to them and inhibiting their function. In addition, since p21 and p27 are target genes of p53, their expression is reduced by E6 in HPV-infected cells. Furthermore, E7 binds and inhibits class I histone deacetylases, whose activity is important for E2F2-mediated transcription and progression through S-phase [127, 128]. In addition to E7, several groups have also implicated E5 as an activator of cellular proliferation. Of particular importance to this process is the ability of E5 to interfere with the degradation and/or trafficking of the epidermal growth factor receptor and which leads to the sustained 
activation of epidermal growth factor signalling [129]. However, since E5 expression is commonly lost after integration, its role may be important only in the early stages of carcinogenesis $[130,131]$.

Normal proliferating cells can only divide a limited number of times, since their lifespan is restricted by telomere shortening that occurs at each cell division. This erosion of telomeres ultimately leads to senescence or cell death and it is thought to be a mechanism used in prevention of unlimited cell growth [132]. During tumorigenesis, the activation of the telomerase enzymatic component hTERT usually occurs to thwart this natural proliferation barrier and promote cellular immortalization. Not surprisingly, telomerase activity is detected in many cancer cells, as well as in numerous cervical lesions and neoplasia [133, 134]. Reactivation of hTERT activity, when combined with $\mathrm{pRb}$ inactivation, has been suggested to be an essential step in the process of immortalization [135]. Although reactivation of telomerase activity in cancer cells commonly arises from genetic alterations, HPV has been shown to possess intrinsic mechanisms for that purpose. Activation of hTERT has been observed in HPV16 E6-expressing cells and it is thought to be, at least inpart, duetoanincreaseinhTERTtranscriptionbrought about by the cooperative binding of E6 and Myc at the hTERT promoter [136]. It has also been shown that hTERT induction is not simply caused by Myc activation, but rather results from a combinatorial effect with other transcription factors such as Sp1 [137]. E6 activation of hTERT was reported to depend on its association with E6-AP, possibly implicating the degradation of a hTERT regulator or transcriptional repressor, with NFX1-91 postulated to be one of these repressors [138-140]. However, not all studies have found a need for E6-AP in hTERT induction [141]. Collectively, these findings indicate that telomerase activation is directly induced by HPV, primarily through a stimulatory effect of E6 on transcription from the hTERT promoter.

\section{Inhibition of p53-Independent Cell Death}

Sustained uncontrolled cellular proliferation and accumulation of genomic alterations often trigger apoptosis. As described above, a major function of E6 is to antagonize p53 in order to prevent the p53-dependent apoptosis that results from the action of E7. However, experiments in p53-null mice showed that E6 is also able to inhibit other p53-independent apoptotic pathways, supporting other functions for this protein in viral carcinogenesis (fig. 4) [142]. Specifically, E6 was shown to inhibit Bax [143] and to mediate the E6-APdependent degradation of Bak [144] by the proteasome, a mechanism conserved among high- and low-risk HPV types [145]. Furthermore, since Bax and Bak expression is regulated by p53, their levels are lower in E6-expressing cells. Interestingly, Bak is highly expressed in the upper layers of the stratified epithelium, making it a potentially important barrier for HPVs [146]. In the context of viral infection, apoptosis is commonly triggered by extrinsic signalling from the family of death receptors [147]. HPV ensures cell survival by interacting with these signalling pathways, such as the one activated by TNF- $a$, and possibly TRAIL and Fas [148-151]. Many other potential pro-apoptotic proteins reported to interact with HPV have been described and are reviewed elsewhere [152]. Prevention of apoptosis is also suspected to allow UV-damaged HPV-positive keratinocytes to progress to nonmelanoma skin cancer [153]. Overall, HPVs possess numerous mechanisms to circumvent apoptosis, which is essential to allow productive infection that is also persistent. 


\section{Tissue Integrity and Invasion}

Cellular anchorage to ECM is essential for most normal cells to progress through the cell cycle. Loss of this interaction not only restricts proliferation, but also induces an apoptotic pathway, referred to as anoikis [154]. This cellular mechanism prevents dysplastic growth and is one of the natural barriers to tumorigenesis [155]. Connection between ECM and the cytoskeleton is mediated through numerous proteins, forming complex macromolecular structures called focal adhesions. These protein complexes, which are important to achieve proper tissue architecture and cohesion, possess intrinsic signalling properties to control cell growth and survival. It is not surprising that HPV proteins can interfere with these molecules through several means in order to prevent anoikis and promote tissue invasion by infected cells [84]. Specifically, E6 was found to interact with many focal adhesion molecules, including Paxillin, Zyxin and Fibulin-1, disrupting interaction between the cytoskeleton and the ECM [156-159]. It was also shown recently that E7 interacts directly with the retinoblastoma protein associated factor p600, and hence may facilitate anchorageindependent cell proliferation [160].

E6 also interacts with several cellular PDZ domain-containing proteins involved in cell adhesion, proliferation, and apicobasal polarity, to promote their proteasomal degradation through E6-AP-dependent and -independent mechanisms. The effect of E6 on these proteins, many of which have tumor suppressor properties [161], disrupts normal cell adhesion, contributes to tissue invasion and metastasis, and favours proliferation of supra-basal epithelial cells. Inhibition of PDZ domain-containing proteins is a mechanism highly conserved among high-risk HPV types to induce hyperplasia [88, 89]. An unusual example of this conservation is the finding that Rhesus papillomavirus targets PDZ domaincontaining proteins using its E7 protein rather than through E6 [162].

\section{Immune Evasion}

Like many viruses, HPV has developed mechanisms to escape immune surveillance. This is of particular significance when considering that cervical carcinogenesis is linked to HPV persistence. One means by which HPV escapes immune detection is built into its natural life cycle. Primary infection occurs in the basal cells of the stratified epithelium where viral genomes are maintained only at very low levels. Viral proteins are also very weakly expressed and confined mainly to the nucleus of basal cells. Increased protein expression only occurs as keratinocytes migrate through the upper layers of the epithelium where the adaptive immune system has limited access. Finally, newly assembled viral particles are released by natural shedding, a process that does not involve cell lysis, thereby preventing dendritic cell activation, pro-inflammatory cytokine liberation, and antigen presentation by Langerhans cells in the proximal layers of the epithelium [163, 164]. HPV has also evolved mechanisms to counteract intracellular antiviral defense pathways. An interferon (IFN) response is usually triggered upon viral infection, which proceeds through IFN- $\alpha$ and IFN- $\beta$ secretion, both of which harbour anti-proliferative and pro-apoptotic abilities. Interferon immunoregulatory effects were shown to be directly inhibited by HPV, both by reducing interferon expression and by interfering with its signalling pathways (reviewed in [165]). Gene expression profiling studies have shown that HPV-31 downregulates IFN-responsive 
genes [166]. Furthermore, E6 is known to physically interact with IRF-3 and inhibit its transactivation ability, and by doing so blocks IFN- $\beta$ expression [167]. HPV-18 E6 has also been proposed to interact with and impair activation of Tyk2, an important mediator of IFNreceptor signalling [168]. Simultaneously, E7 can interfere with the IFN response by inhibiting IRF-1 and ISGF-3 [169-171]. Another innate intracellular antiviral response is mediated by the double-stranded RNA protein kinase (PKR), an IFN-inducible protein, which is also targeted by HPV [172]. This protein kinase has been shown to be mis-localized in HPV-infected cells and its phosphorylation level reduced in cells expressing E6 and E7, suggesting a modulation of this pathway by HPV. Moreover, E5 has been proposed to interfere with $\mathrm{MHC} 1$ mediated antigen presentation by deregulating endosomal acidification and trafficking, and thus, prevents immune recognition [173]. Altogether, these immune evasion mechanisms probably function in concert to facilitate viral persistence, a known risk factor for cancer progression.

\section{Conclusion}

The role of HPV infection in carcinogenesis is now well established and the molecular events triggered by viral proteins are becoming better characterized. It is important to realize, however, that the implication of HPV infection in oncogenesis may be an indirect consequence of keeping infected cells in a proliferative state. To ensure replication and maintenance of their genome, HPVs have acquired several mechanisms to usurp the host DNA synthesis machinery, while escaping the host intracellular and immune defenses. Moreover, viral proteins of high-risk HPV types contain distinct features that promote cell growth, despite cellular attempts to initiate apoptosis in response to uncontrolled proliferation and/or disruption of cellular adhesion, which represent natural mechanisms to prevent dysplasia. In some cases, infection becomes suboptimal and results in viral genome integration. This in turn amplifies genomic instability and the acquisition of additional genetic and epigenetic changes needed for cancer progression. Prophylactic vaccines have recently been developed and approved for preventing infection by the 2 most common oncogenic types (HPVs 16 and 18), and those causing most cases of benign genital warts (HPVs 6 and 11). Unfortunately, and despite substantial efforts made towards the discovery of small molecule inhibitors of HPV (reviewed in [39]), antiviral drugs to treat already infected patients are still lacking. It is hoped that a greater understanding of the molecular events involved in viral pathogenesis will ultimately contribute to the development of novel antiviral therapies, as well as serve as a model to understand carcinogenesis in general.

\section{Acknowledgments}

Work in the authors' laboratory is supported by grants from the Canadian Institutes of Health Research (CIHR) and the Cancer Research Society Inc. M.L. is supported by a studentship from the CIHR.

\section{References}

1. Rous P, Beard JW. The progression to carcinoma of virus-induced rabbit papillomas (Shope). J Exp Med. 1935; 62:523-548. [PubMed: 19870432]

2. Shope RE, Hurst EW. Infectious papillomatosis of rabbits: with a note on the histopathology. J Exp Med. 1933; 58:607-624. [PubMed: 19870219] 
3. Gissmann L, zur Hausen H. Partial characterization of viral DNA from human genital warts (Condylomata acuminata). Int J Cancer. 1980; 25:605-609. [PubMed: 6246010]

4. Durst M, Gissmann L, Ikenberg H, zur Hausen H. A papillomavirus DNA from a cervical carcinoma and its prevalence in cancer biopsy samples from different geographic regions. Proc Natl Acad Sci USA. 1983; 80:3812-3815. [PubMed: 6304740]

5. de Martel C, Franceschi S. Infections and cancer: established associations and new hypotheses. Crit Rev Oncol Hematol. 2008 E-pub ahead of print.

6. Parkin DM. The global health burden of infection-associated cancers in the year 2002. Int J Cancer. 2006; 118:3030-3044. [PubMed: 16404738]

7. de Villiers EM, Fauquet C, Broker TR, Bernard HU, zur Hausen H. Classification of papillomaviruses. Virology. 2004; 324:17-27. [PubMed: 15183049]

8. Rous P, Kidd JG, Beard JW. Observations on the relation of the virus causing rabbit papillomas to the cancers deriving therefrom. 1 . The influence of the host species and of the pathogenic activity and concentration of the virus. J Exp Med. 1936; 64:385-400. [PubMed: 19870543]

9. Stanley MA, Pett MR, Coleman N. HPV: from infection to cancer. Biochem Soc Trans. 2007; 35:1456-1460. [PubMed: 18031245]

10. Baseman JG, Koutsky LA. The epidemiology of human papillomavirus infections. J Clin Virol. 2005; 32(suppl 1):S16-S24. [PubMed: 15753008]

11. Schiffman M, Kjaer SK. Chapter 2: Natural history of anogenital human papillomavirus infection and neoplasia. J Natl Cancer Inst Monogr. 2003; 31:14-19.

12. zur Hausen H. Papillomavirus infections: a major cause of human cancers. Biochim Bio-phys Acta. 1996; 1288:F55-F78.

13. Bosch FX, Lorincz A, Munoz N, Meijer CJ, Shah KV. The causal relation between human papillomavirus and cervical cancer. J Clin Pathol. 2002; 55:244-265. [PubMed: 11919208]

14. Parkin DM, Bray F, Ferlay J, Pisani P. Global Cancer Statistics, 2002. CA Cancer J Clin. 2005; 55:74-108. [PubMed: 15761078]

15. Castellsagué X, de Sanjosé S, Aguado T, Louie KS, Bruni L, Munoz J, Diaz M, Irwin K, Gacic M, Beauvais O, Albero G, Ferrer E, Byrne S, Bosch FX. HPV and cervical cancer in the World: 2007 Report. Vaccine. 2007; 25:C1-C26. [PubMed: 18068032]

16. Jemal A, Siegel R, Ward E, Hao Y, Xu J, Murray T, Thun MJ. Cancer Statistics, 2008. CA Cancer J Clin. 2008; 58:71-96. [PubMed: 18287387]

17. Hoory T, Monie A, Gravitt P, Wu TC. Molecular epidemiology of human papillomavirus. J Formos Med Assoc. 2008; 107:198-217. [PubMed: 18400605]

18. Gillison ML, Koch WM, Capone RB, Spafford M, Westra WH, Wu L, Zahurak ML, Daniel RW, Viglione M, Symer DE, Shah KV, Sidransky D. Evidence for a causal association between human papillomavirus and a subset of head and neck cancers. J Natl Cancer Inst. 2000; 92:709-720. [PubMed: 10793107]

19. Kreimer AR, Clifford GM, Boyle P, Frances-chi S. Human papillomavirus types in head and neck squamous cell carcinomas worldwide: a systematic review. Cancer Epidemiol Biomarkers Prev. 2005; 14:467-475. [PubMed: 15734974]

20. Syrjanen S. Human papillomavirus (HPV) in head and neck cancer. J Clin Virol. 2005; 32(suppl 1):S59-S66. [PubMed: 15753013]

21. Syrjanen S. Human papillomaviruses in head and neck carcinomas. N Engl J Med. 2007; 356:1993-1995. [PubMed: 17494934]

22. zur Hausen H. Papillomaviruses and cancer: from basic studies to clinical application. Nat Rev Cancer. 2002; 2:342-350. [PubMed: 12044010]

23. Walboomers JM, Jacobs MV, Manos MM, Bosch FX, Kummer JA, Shah KV, Snijders PJ, Peto J, Meijer CJ, Munoz N. Human papillomavirus is a necessary cause of invasive cervical cancer worldwide. J Pathol. 1999; 189:12-19. [PubMed: 10451482]

24. Bohmer G, van den Brule AJ, Brummer O, Meijer CL, Petry KU. No confirmed case of human papillomavirus DNA-negative cervical intraepithelial neoplasia grade 3 or invasive primary cancer of the uterine cervix among 511 patients. Am J Obstet Gynecol. 2003; 189:118-120. [PubMed: 12861148] 
25. Daling JR, Madeleine MM, Johnson LG, Schwartz SM, Shera KA, Wurscher MA, Carter JJ, Porter PL, Galloway DA, McDougall JK. Human papillomavirus, smoking, and sexual practices in the etiology of anal cancer. Cancer. 2004; 101:270-280. [PubMed: 15241823]

26. Frisch M, Fenger C, van den Brule AJ, Sorensen P, Meijer CJ, Walboomers JM, Adami HO, Melbye M, Glimelius B. Variants of squamous cell carcinoma of the anal canal and perianal skin and their relation to human papillomaviruses. Cancer Res. 1999; 59:753-757. [PubMed: 9973228]

27. Partridge JM, Koutsky LA. Genital human papillomavirus infection in men. Lancet Infect Dis. 2006; 6:21-31. [PubMed: 16377531]

28. Frisch M, Biggar RJ, Goedert JJ. Human papillomavirus-associated cancers in patients with human immunodeficiency virus infection and acquired immunodeficiency syndrome. J Natl Cancer Inst. 2000; 92:1500-1510. [PubMed: 10995805]

29. Nindl I, Rosl F. Molecular concepts of virus infections causing skin cancer in organ transplant recipients. Am J Transplant. 2008; 8:2199-2204. [PubMed: 18785959]

30. Shamanin V, zur Hausen H, Lavergne D, Proby CM, Leigh IM, Neumann C, Hamm H, Goos M, Haustein UF, Jung EG, Plewig G, Wolff H, de Villiers EM. Human papillomavirus infections in nonmelanoma skin cancers from renal transplant recipients and nonimmunosuppressed patients. $\mathrm{J}$ Natl Cancer Inst. 1996; 88:802-811. [PubMed: 8637046]

31. Harwood CA, McGregor JM, Proby CM, Breuer J. Human papillomavirus and the development of non-melanoma skin cancer. J Clin Pathol. 1999; 52:249-253. [PubMed: 10474513]

32. de Sanjose S, Palefsky J. Cervical and anal HPV infections in HIV positive women and men. Virus Res. 2002; 89:201-211. [PubMed: 12445660]

33. Fakhry C, D’Souza G, Sugar E, Weber K, Goshu E, Minkoff H, Wright R, Seaberg E, Gillison M. Relationship between prevalent oral and cervical human papillomavirus infections in human immunodeficiency virus-positive and -negative women. J Clin Microbiol. 2006; 44:4479-4485. [PubMed: 17021055]

34. Doorbar J. Molecular biology of human papillomavirus infection and cervical cancer. Clin Sci (Lond). 2006; 110:525-541. [PubMed: 16597322]

35. Hebner CM, Laimins LA. Human papillomaviruses: basic mechanisms of pathogenesis and oncogenicity. Rev Med Virol. 2006; 16:83-97. [PubMed: 16287204]

36. Bousarghin L, Touze A, Sizaret PY, Coursaget P. Human papillomavirus types 16, 31, and 58 use different endocytosis pathways to enter cells. J Virol. 2003; 77:3846-3850. [PubMed: 12610160]

37. Joyce JG, Tung JS, Przysiecki CT, Cook JC, Lehman ED, Sands JA, Jansen KU, Keller PM. The L1 major capsid protein of human papillomavirus type 11 recombinant virus-like particles interacts with heparin and cell-surface glycosaminoglycans on human keratinocytes. J Biol Chem. 1999; 274:5810-5822. [PubMed: 10026203]

38. Florin L, Becker KA, Lambert C, Nowak T, Sapp C, Strand D, Streeck RE, Sapp M. Identification of a dynein interacting domain in the papillomavirus minor capsid protein L2. J Virol. 2006; 80:6691-6696. [PubMed: 16775357]

39. Fradet-Turcotte A, Archambault J. Recent advances in the search for antiviral agents against human papillomaviruses. Antivir Ther. 2007; 12:431-451. [PubMed: 17668552]

40. Bouvard V, Storey A, Pim D, Banks L. Characterization of the human papillomavirus E2 protein: evidence of trans-activation and trans-repression in cervical keratinocytes. EMBO J. 1994; 13:5451-5459. [PubMed: 7957111]

41. Steger G, Corbach S. Dose-dependent regulation of the early promoter of human papillomavirus type 18 by the viral E2 protein. J Virol. 1997; 71:50-58. [PubMed: 8985322]

42. McBride AA, McPhillips MG, Oliveira JG. Brd4: tethering, segregation and beyond. Trends Microbiol. 2004; 12:527-529. [PubMed: 15539109]

43. Senechal H, Poirier GG, Coulombe B, Laimins LA, Archambault J. Amino acid substitutions that specifically impair the transcriptional activity of papillomavirus E2 affect binding to the long isoform of Brd4. Virology. 2007; 358:10-17. [PubMed: 17023018]

44. Fehrmann F, Klumpp DJ, Laimins LA. Human papillomavirus type 31 E5 protein supports cell cycle progression and activates late viral functions upon epithelial differentiation. J Virol. 2003; 77:2819-2831. [PubMed: 12584305] 
45. Genther SM, Sterling S, Duensing S, Munger K, Sattler C, Lambert PF. Quantitative role of the human papillomavirus type 16 E5 gene during the productive stage of the viral life cycle. J Virol. 2003; 77:2832-2842. [PubMed: 12584306]

46. Wilson R, Fehrmann F, Laimins LA. Role of the E1-E4 protein in the differentiation-dependent life cycle of human papillomavirus type 31. J Virol. 2005; 79:6732-6740. [PubMed: 15890911]

47. Durst M, Kleinheinz A, Hotz M, Gissmann L. The physical state of human papillomavirus type 16 DNA in benign and malignant genital tumours. J Gen Virol. 1985; 66:1515-1522. [PubMed: 2991428]

48. Ziegert C, Wentzensen N, Vinokurova S, Kisseljov F, Einenkel J, Hoeckel M, von Knebel Doeberitz M. A comprehensive analysis of HPV integration loci in anogenital lesions combining transcript and genome-based amplification techniques. Oncogene. 2003; 22:3977-3984. [PubMed: 12813471]

49. Wentzensen N, Vinokurova S, von Knebel Doeberitz M. Systematic review of genomic integration sites of human papillomavirus genomes in epithelial dysplasia and invasive cancer of the female lower genital tract. Cancer Res. 2004; 64:3878-3884. [PubMed: 15172997]

50. Durst M, Croce CM, Gissmann L, Schwarz E, Huebner K. Papillomavirus sequences integrate near cellular oncogenes in some cervical carcinomas. Proc Natl Acad Sci USA. 1987; 84:1070-1074. [PubMed: 3029760]

51. Ferber MJ, Montoya DP, Yu C, Aderca I, McGee A, Thorland EC, Nagorney DM, Gostout BS, Burgart LJ, Boix L, Bruix J, McMahon BJ, Cheung TH, Chung TK, Wong YF, Smith DI, Roberts LR. Integrations of the hepatitis B virus (HBV) and human papillomavirus (HPV) into the human telomerase reverse transcriptase (hTERT) gene in liver and cervical cancers. Oncogene. 2003; 22:3813-3820. [PubMed: 12802289]

52. Ferber MJ, Thorland EC, Brink AA, Rapp AK, Phillips LA, McGovern R, Gostout BS, Cheung TH, Chung TK, Fu WY, Smith DI. Preferential integration of human papillomavirus type 18 near the c-myc locus in cervical carcinoma. Oncogene. 2003; 22:7233-7242. [PubMed: 14562053]

53. Popescu NC, DiPaolo JA. Integration of human papillomavirus 16 DNA and genomic rearrangements in immortalized human keratinocyte lines. Cancer Res. 1990; 50:1316-1323. [PubMed: 2153457]

54. Baker CC, Phelps WC, Lindgren V, Braun MJ, Gonda MA, Howley PM. Structural and transcriptional analysis of human papillomavirus type 16 sequences in cervical carcinoma cell lines. J Virol. 1987; 61:962-971. [PubMed: 3029430]

55. Woodworth CD, Doniger J, DiPaolo JA. Immortalization of human foreskin keratinocytes by various human papillomavirus DNAs corresponds to their association with cervical carcinoma. $\mathrm{J}$ Virol. 1989; 63:159-164. [PubMed: 2462058]

56. DeFilippis RA, Goodwin EC, Wu L, DiMaio D. Endogenous human papillomavirus E6 and E7 proteins differentially regulate proliferation, senescence, and apoptosis in HeLa cervical carcinoma cells. J Virol. 2003; 77:1551-1563. [PubMed: 12502868]

57. Hawley-Nelson P, Vousden KH, Hubbert NL, Lowy DR, Schiller JT. HPV16 E6 and E7 proteins cooperate to immortalize human foreskin keratinocytes. EMBO J. 1989; 8:3905-3910. [PubMed: 2555178]

58. Munger K, Phelps WC, Bubb V, Howley PM, Schlegel R. The E6 and E7 genes of the human papillomavirus type 16 together are necessary and sufficient for transformation of primary human keratinocytes. J Virol. 1989; 63:4417-4421. [PubMed: 2476573]

59. Moon MS, Lee CJ, Um SJ, Park JS, Yang JM, Hwang ES. Effect of BPV1 E2-mediated inhibition of E6/E7 expression in HPV16-positive cervical carcinoma cells. Gynecol Oncol. 2001; 80:168175. [PubMed: 11161855]

60. Nishimura A, Nakahara T, Ueno T, Sasaki K, Yoshida S, Kyo S, Howley PM, Sakai H. Requirement of E7 oncoprotein for viability of HeLa cells. Microbes Infect. 2006; 8:984-993. [PubMed: 16500131]

61. Herber R, Liem A, Pitot H, Lambert PF. Squamous epithelial hyperplasia and carcinoma in mice transgenic for the human papillomavirus type 16 E7 oncogene. J Virol. 1996; 70:1873-1881.

[PubMed: 8627712] 
62. Song S, Pitot HC, Lambert PF. The human papillomavirus type 16 E6 gene alone is sufficient to induce carcinomas in transgenic animals. J Virol. 1999; 73:5887-5893. [PubMed: 10364340]

63. Kanda T, Watanabe S, Yoshiike K. Immortalization of primary rat cells by human papillomavirus type 16 subgenomic DNA fragments controlled by the SV40 promoter. Virology. 1988; 165:321325. [PubMed: 2838969]

64. Yasumoto S, Burkhardt AL, Doniger J, DiPaolo JA. Human papillomavirus type 16 DNA-induced malignant transformation of NIH 3T3 cells. J Virol. 1986; 57:572-577. [PubMed: 3003388]

65. Riley RR, Duensing S, Brake T, Munger K, Lambert PF, Arbeit JM. Dissection of human papillomavirus E6 and E7 function in transgenic mouse models of cervical carcinogenesis. Cancer Res. 2003; 63:4862-4871. [PubMed: 12941807]

66. Phelps WC, Yee CL, Munger K, Howley PM. The human papillomavirus type 16 E7 gene encodes transactivation and transformation functions similar to those of adenovirus E1A. Cell. 1988; 53:539-547. [PubMed: 2836062]

67. Dyson N, Howley PM, Munger K, Harlow E. The human papilloma virus-16 E7 oncoprotein is able to bind to the retinoblastoma gene product. Science. 1989; 243:934-937. [PubMed: 2537532]

68. Gonzalez SL, Stremlau M, He X, Basile JR, Munger K. Degradation of the retinoblastoma tumor suppressor by the human papillomavirus type $16 \mathrm{E} 7$ oncoprotein is important for functional inactivation and is separable from proteasomal degradation of E7. J Virol. 2001; 75:7583-7591. [PubMed: 11462030]

69. Zhang B, Chen W, Roman A. The E7 proteins of low- and high-risk human papillomaviruses share the ability to target the pRB family member p130 for degradation. Proc Natl Acad Sci USA. 2006; 103:437-442. [PubMed: 16381817]

70. Huh K, Zhou X, Hayakawa H, Cho JY, Libermann TA, Jin J, Harper JW, Munger K. Human papillomavirus type $16 \mathrm{E} 7$ oncoprotein associates with the cullin 2 ubiquitin ligase complex, which contributes to degradation of the retinoblastoma tumor suppressor. J Virol. 2007; 81:97379747. [PubMed: 17609271]

71. Phelps WC, Munger K, Yee CL, Barnes JA, Howley PM. Structure-function analysis of the human papillomavirus type 16 E7 oncoprotein. J Virol. 1992; 66:2418-2427. [PubMed: 1312637]

72. Jones DL, Thompson DA, Munger K. Destabilization of the RB tumor suppressor protein and stabilization of p53 contribute to HPV type 16 E7-induced apoptosis. Virology. 1997; 239:97-107. [PubMed: 9426450]

73. Huibregtse JM, Scheffner M, Beaudenon S, Howley PM. A family of proteins structurally and functionally related to the E6-AP ubiquitin-protein ligase. Proc Natl Acad Sci USA. 1995; 92:2563-2567. [PubMed: 7708685]

74. Beer-Romero P, Glass S, Rolfe M. Antisense targeting of E6AP elevates p53 in HPV-infected cells but not in normal cells. Oncogene. 1997; 14:595-602. [PubMed: 9053858]

75. Huibregtse JM, Scheffner M, Howley PM. A cellular protein mediates association of p53 with the E6 oncoprotein of human papillomavirus types 16 or 18. EMBO J. 1991; 10:4129-4135. [PubMed: 1661671]

76. Band V, De Caprio JA, Delmolino L, Kulesa V, Sager R. Loss of p53 protein in human papillomavirus type 16 E6-immortalized human mammary epithelial cells. J Virol. 1991; 65:66716676. [PubMed: 1658367]

77. Dalal S, Gao Q, Androphy EJ, Band V. Mutational analysis of human papillomavirus type 16 E6 demonstrates that p53 degradation is necessary for immortalization of mammary epithelial cells. $\mathbf{J}$ Virol. 1996; 70:683-688. [PubMed: 8551603]

78. Talis AL, Huibregtse JM, Howley PM. The role of E6AP in the regulation of p53 protein levels in human papillomavirus (HPV)-positive and HPV-negative cells. J Biol Chem. 1998; 273:64396445. [PubMed: 9497376]

79. Mantovani F, Banks L. Inhibition of E6 induced degradation of p53 is not sufficient for stabilization of p53 protein in cervical tumour derived cell lines. Oncogene. 1999; 18:3309-3315. [PubMed: 10362351]

80. Patel D, Huang SM, Baglia LA, McCance DJ. The E6 protein of human papillomavirus type 16 binds to and inhibits co-activation by CBP and p300. EMBO J. 1999; 18:5061-5072. [PubMed: 10487758] 
81. Zimmermann H, Degenkolbe R, Bernard HU, O'Connor MJ. The human papillomavirus type 16 E6 oncoprotein can down-regulate p53 activity by targeting the transcriptional coactivator CBP/ p300. J Virol. 1999; 73:6209-6219. [PubMed: 10400710]

82. Li X, Coffino P. High-risk human papillomavirus E6 protein has two distinct binding sites within p53, of which only one determines degradation. J Virol. 1996; 70:4509-4516. [PubMed: 8676476]

83. Brimer N, Lyons C, Vande Pol SB. Association of E6AP (UBE3A) with human papillomavirus type 11 E6 protein. Virology. 2007; 358:303-310. [PubMed: 17023019]

84. Mantovani F, Banks L. The human papillomavirus E6 protein and its contribution to malignant progression. Oncogene. 2001; 20:7874-7887. [PubMed: 11753670]

85. Storrs CH, Silverstein SJ. PATJ, a tight junction-associated PDZ protein, is a novel degradation target of high-risk human papillomavirus E6 and the alternatively spliced isoform 18 E6. J Virol. 2007; 81:4080-4090. [PubMed: 17287269]

86. Favre-Bonvin A, Reynaud C, Kretz-Remy C, Jalinot P. Human papillomavirus type 18 E6 protein binds the cellular PDZ protein TIP-2/GIPC, which is involved in transforming growth factor beta signaling and triggers its degradation by the proteasome. J Virol. 2005; 79:4229-4237. [PubMed: 15767424]

87. Spanos WC, Hoover A, Harris GF, Wu S, Strand GL, Anderson ME, Klingelhutz AJ, Hendriks W, Bossler AD, Lee JH. The PDZ binding motif of human papillomavirus type 16 E6 induces PTPN13 loss, which allows anchorage-independent growth and synergizes with ras for invasive growth. J Virol. 2008; 82:2493-2500. [PubMed: 18160445]

88. Lee C, Laimins LA. Role of the PDZ domain-binding motif of the oncoprotein E6 in the pathogenesis of human papillomavirus type 31. J Virol. 2004; 78:12366-12377. [PubMed: 15507623]

89. Nguyen ML, Nguyen MM, Lee D, Griep AE, Lambert PF. The PDZ ligand domain of the human papillomavirus type 16 E6 protein is required for E6's induction of epithelial hyperplasia in vivo. J Virol. 2003; 77:6957-6964. [PubMed: 12768014]

90. Shai A, Brake T, Somoza C, Lambert PF. The human papillomavirus E6 oncogene dysregulates the cell cycle and contributes to cervical carcinogenesis through two independent activities. Cancer Res. 2007; 67:1626-1635. [PubMed: 17308103]

91. Pim D, Massimi P, Banks L. Alternatively spliced HPV-18 E6* protein inhibits E6 mediated degradation of p53 and suppresses transformed cell growth. Oncogene. 1997; 15:257-264. [PubMed: 9233760]

92. Hurlin PJ, Kaur P, Smith PP, Perez-Reyes N, Blanton RA, McDougall JK. Progression of human papillomavirus type 18-immortalized human keratinocytes to a malignant phenotype. Proc Natl Acad Sci USA. 1991; 88:570-574. [PubMed: 1846447]

93. Hanahan D, Weinberg RA. The hallmarks of cancer. Cell. 2000; 100:57-70. [PubMed: 10647931]

94. Alonio LV, Picconi MA, Dalbert D, Mural J, Bartt O, Bazan G, Dominguez M, Teyssie AR. Haras oncogene mutation associated to progression of papillomavirus induced lesions of uterine cervix. $\mathrm{J}$ Clin Virol. 2003; 27:263-269. [PubMed: 12878090]

95. Grendys EC Jr, Barnes WA, Weitzel J, Sparkowski J, Schlegel R. Identification of H, K, and N-ras point mutations in stage IB cervical carcinoma. Gynecol Oncol. 1997; 65:343-347. [PubMed: 9159349]

96. Crook T, Storey A, Almond N, Osborn K, Crawford L. Human papillomavirus type 16 cooperates with activated ras and fos oncogenes in the hormone-dependent transformation of primary mouse cells. Proc Natl Acad Sci USA. 1988; 85:8820-8824. [PubMed: 2848240]

97. Matlashewski G, Schneider J, Banks L, Jones N, Murray A, Crawford L. Human papillomavirus type 16 DNA cooperates with activated ras in transforming primary cells. EMBO J. 1987; 6:17411746. [PubMed: 3038534]

98. Klausner RD. The fabric of cancer cell biology: weaving together the strands. Cancer Cell. 2002; 1:3-10. [PubMed: 12086880]

99. Duensing S, Munger K. Human papillomaviruses and centrosome duplication errors: modeling the origins of genomic instability. Oncogene. 2002; 21:6241-6248. [PubMed: 12214255] 
100. White AE, Livanos EM, Tlsty TD. Differential disruption of genomic integrity and cell cycle regulation in normal human fibroblasts by the HPV oncoproteins. Genes Dev. 1994; 8:666-677. [PubMed: 7926757]

101. Hashida T, Yasumoto S. Induction of chromosome abnormalities in mouse and human epidermal keratinocytes by the human papillomavirus type 16 E7 oncogene. J Gen Virol. 1991; 72:15691577. [PubMed: 1649895]

102. Pett MR, Alazawi WO, Roberts I, Dowen S, Smith DI, Stanley MA, Coleman N. Acquisition of high-level chromosomal instability is associated with integration of human papillomavirus type 16 in cervical keratinocytes. Cancer Res. 2004; 64:1359-1368. [PubMed: 14973079]

103. Vermeulen CF, Jordanova ES, Szuhai K, Kolkman-Uljee S, Vrede MA, Peters AA, Schuuring E, Fleuren GJ. Physical status of multiple human papillomavirus genotypes in flow-sorted cervical cancer cells. Cancer Genet Cytogenet. 2007; 175:132-137. [PubMed: 17556069]

104. Cahill DP, Kinzler KW, Vogelstein B, Lengauer C. Genetic instability and darwinian selection in tumours. Trends Cell Biol. 1999; 9:M57-M60. [PubMed: 10611684]

105. Duensing S, Munger K. Centrosome abnormalities and genomic instability induced by human papillomavirus oncoproteins. Prog Cell Cycle Res. 2003; 5:383-391. [PubMed: 14593733]

106. Thomas JT, Laimins LA. Human papillomavirus oncoproteins E6 and E7 independently abrogate the mitotic spindle checkpoint. J Virol. 1998; 72:1131-1137. [PubMed: 9445009]

107. Thompson DA, Belinsky G, Chang TH, Jones DL, Schlegel R, Munger K. The human papillomavirus-16 E6 oncoprotein decreases the vigilance of mitotic checkpoints. Oncogene. 1997; 15:3025-3035. [PubMed: 9444951]

108. Southern SA, Noya F, Meyers C, Broker TR, Chow LT, Herrington CS. Tetrasomy is induced by human papillomavirus type 18 E7 gene expression in keratinocyte raft cultures. Cancer Res. 2001; 61:4858-4863. [PubMed: 11406563]

109. Duensing S, Duensing A, Crum CP, Munger K. Human papillomavirus type 16 E7 oncoproteininduced abnormal centrosome synthesis is an early event in the evolving malignant phenotype. Cancer Res. 2001; 61:2356-2360. [PubMed: 11289095]

110. Weitzman MD, Carson CT, Schwartz RA, Lilley CE. Interactions of viruses with the cellular DNA repair machinery. DNA Repair (Amst). 2004; 3:1165-1173. [PubMed: 15279805]

111. Patel KJ, Joenje H. Fanconi anemia and DNA replication repair. DNA Repair (Amst). 2007; 6:885-890. [PubMed: 17481966]

112. Wang W. Emergence of a DNA-damage response network consisting of Fanconi anaemia and BRCA proteins. Nat Rev Genet. 2007; 8:735-748. [PubMed: 17768402]

113. Kutler DI, Wreesmann VB, Goberdhan A, Ben-Porat L, Satagopan J, Ngai I, Huvos AG, Giampietro P, Levran O, Pujara K, Diotti R, Carlson D, Huryn LA, Auerbach AD, Singh B. Human papillomavirus DNA and p53 polymorphisms in squamous cell carcinomas from Fanconi anemia patients. J Natl Cancer Inst. 2003; 95:1718-1721. [PubMed: 14625263]

114. Narayan G, Arias-Pulido H, Nandula SV, Basso K, Sugirtharaj DD, Vargas H, Mansukhani M, Villella J, Meyer L, Schneider A, Gissmann L, Durst M, Pothuri B, Murty VV. Promoter hypermethylation of FANCF: disruption of Fanconi Anemia-BRCA pathway in cervical cancer. Cancer Res. 2004; 64:2994-2997. [PubMed: 15126331]

115. Dong SM, Kim HS, Rha SH, Sidransky D. Promoter hypermethylation of multiple genes in carcinoma of the uterine cervix. Clin Cancer Res. 2001; 7:1982-1986. [PubMed: 11448914]

116. Feng Q, Balasubramanian A, Hawes SE, Toure P, Sow PS, Dem A, Dembele B, Critchlow CW, Xi L, Lu H, McIntosh MW, Young AM, Kiviat NB. Detection of hyper-methylated genes in women with and without cervical neoplasia. J Natl Cancer Inst. 2005; 97:273-282. [PubMed: 15713962]

117. Sova P, Feng Q, Geiss G, Wood T, Strauss R, Rudolf V, Lieber A, Kiviat N. Discovery of novel methylation biomarkers in cervical carcinoma by global demethylation and microarray analysis. Cancer Epidemiol Biomarkers Prev. 2006; 15:114-123. [PubMed: 16434596]

118. Spardy N, Duensing A, Charles D, Haines N, Nakahara T, Lambert PF, Duensing S. The human papillomavirus type $16 \mathrm{E} 7$ oncoprotein activates the Fanconi anemia (FA) pathway and causes accelerated chromosomal instability in FA cells. J Virol. 2007; 81:13265-13270. [PubMed: 17898070] 
119. Hoskins EE, Gunawardena RW, Habash KB, Wise-Draper TM, Jansen M, Knudsen ES, Wells SI. Coordinate regulation of Fanconi anemia gene expression occurs through the Rb/E2F pathway. Oncogene. 2008; 27:4798-4808. [PubMed: 18438432]

120. Howlett NG, Taniguchi T, Durkin SG, D'Andrea AD, Glover TW. The Fanconi anemia pathway is required for the DNA replication stress response and for the regulation of common fragile site stability. Hum Mol Genet. 2005; 14:693-701. [PubMed: 15661754]

121. Thorland EC, Myers SL, Gostout BS, Smith DI. Common fragile sites are preferential targets for HPV16 integrations in cervical tumors. Oncogene. 2003; 22:1225-1237. [PubMed: 12606949]

122. Wang Y, Wiltshire T, Senft J, Wenger SL, Reed E, Wang W. Fanconi anemia D2 protein confers chemoresistance in response to the anticancer agent, irofulven. Mol Cancer Ther. 2006; 5:31533161. [PubMed: 17172419]

123. He W, Staples D, Smith C, Fisher C. Direct activation of cyclin-dependent kinase 2 by human papillomavirus E7. J Virol. 2003; 77:10566-10574. [PubMed: 12970441]

124. Funk JO, Waga S, Harry JB, Espling E, Stillman B, Galloway DA. Inhibition of CDK activity and PCNA-dependent DNA replication by $\mathrm{p} 21$ is blocked by interaction with the HPV-16 E7 oncoprotein. Genes Dev. 1997; 11:2090-2100. [PubMed: 9284048]

125. Jones DL, Alani RM, Munger K. The human papillomavirus E7 oncoprotein can uncouple cellular differentiation and proliferation in human keratinocytes by abrogating p21Cip1-mediated inhibition of cdk2. Genes Dev. 1997; 11:2101-2111. [PubMed: 9284049]

126. Zerfass-Thome K, Zwerschke W, Mannhardt B, Tindle R, Botz JW, Jansen-Durr P. Inactivation of the cdk inhibitor p27KIP1 by the human papillomavirus type 16 E7 oncoprotein. Oncogene. 1996; 13:2323-2330. [PubMed: 8957073]

127. Longworth MS, Laimins LA. The binding of histone deacetylases and the integrity of zinc fingerlike motifs of the $\mathrm{E} 7$ protein are essential for the life cycle of human papillomavirus type 31 . J Virol. 2004; 78:3533-3541. [PubMed: 15016876]

128. Longworth MS, Wilson R, Laimins LA. HPV31 E7 facilitates replication by activating E2F2 transcription through its interaction with HDACs. EMBO J. 2005; 24:1821-1830. [PubMed: 15861133]

129. DiMaio D, Mattoon D. Mechanisms of cell transformation by papillomavirus E5 proteins. Oncogene. 2001; 20:7866-7873. [PubMed: 11753669]

130. Shirasawa H, Tomita Y, Sekiya S, Takamizawa H, Simizu B. Integration and transcription of human papillomavirus type 16 and 18 sequences in cell lines derived from cervical carcinomas. J Gen Virol. 1987; 68:583-591. [PubMed: 3029293]

131. Valle GF, Banks L. The human papillomavirus (HPV)-6 and HPV-16 E5 proteins cooperate with HPV-16 E7 in the transformation of primary rodent cells. J Gen Virol. 1995; 76:1239-1245. [PubMed: 7730808]

132. Cong YS, Wright WE, Shay JW. Human telomerase and its regulation. Microbiol Mol Biol Rev. 2002; 66:407-425. [PubMed: 12208997]

133. Shay JW, Bacchetti S. A survey of telomerase activity in human cancer. Eur J Cancer. 1997; 33:787-791. [PubMed: 9282118]

134. Snijders PJ, van Duin M, Walboomers JM, Steenbergen RD, Risse EK, Helmerhorst TJ, Verheijen $\mathrm{RH}$, Meijer CJ. Telomerase activity exclusively in cervical carcinomas and a subset of cervical intraepithelial neoplasia grade III lesions: strong association with elevated messenger RNA levels of its catalytic subunit and high-risk human papillomavirus DNA. Cancer Res. 1998; 58:38123818. [PubMed: 9731489]

135. Kiyono T, Foster SA, Koop JI, McDougall JK, Galloway DA, Klingelhutz AJ. Both Rb/ p16INK4a inactivation and telomerase activity are required to immortalize human epithelial cells. Nature. 1998; 396:84-88. [PubMed: 9817205]

136. Veldman T, Liu X, Yuan H, Schlegel R. Human papillomavirus E6 and Myc proteins associate in vivo and bind to and cooperatively activate the telomerase reverse transcriptase promoter. Proc Natl Acad Sci USA. 2003; 100:8211-8216. [PubMed: 12821782]

137. Oh ST, Kyo S, Laimins LA. Telomerase activation by human papillomavirus type 16 E6 protein: induction of human telomerase reverse transcriptase expression through Myc and GC-rich Sp1 binding sites. J Virol. 2001; 75:5559-5566. [PubMed: 11356963] 
138. Galloway DA, Gewin LC, Myers H, Luo W, Grandori C, Katzenellenbogen RA, McDougall JK Regulation of telomerase by human papillomaviruses. Cold Spring Harb Symp Quant Biol. 2005; 70:209-215. [PubMed: 16869756]

139. Gewin L, Galloway DA. E box-dependent activation of telomerase by human papillomavirus type 16 E6 does not require induction of c-myc. J Virol. 2001; 75:7198-7201. [PubMed: 11435602]

140. Gewin L, Myers H, Kiyono T, Galloway DA. Identification of a novel telomerase repressor that interacts with the human papillomavirus type-16 E6/E6-AP complex. Genes Dev. 2004; 18:22692282. [PubMed: 15371341]

141. Sekaric P, Cherry JJ, Androphy EJ. Binding of human papillomavirus type 16 E6 to E6AP is not required for activation of hTERT. J Virol. 2008; 82:71-76. [PubMed: 17942561]

142. Pan H, Griep AE. Temporally distinct patterns of p53-dependent and p53-independent apoptosis during mouse lens development. Genes Dev. 1995; 9:2157-2169. [PubMed: 7657167]

143. Vogt M, Butz K, Dymalla S, Semzow J, Hoppe-Seyler F. Inhibition of Bax activity is crucial for the antiapoptotic function of the human papillomavirus E6 oncoprotein. Oncogene. 2006; 25:4009-4015. [PubMed: 16462759]

144. Thomas M, Banks L. Inhibition of Bak-induced apoptosis by HPV-18 E6. Oncogene. 1998; 17:2943-2954. [PubMed: 9881696]

145. Thomas M, Banks L. Human papillomavirus (HPV) E6 interactions with Bak are conserved amongst E6 proteins from high and low risk HPV types. J Gen Virol. 1999; 80:1513-1517. [PubMed: 10374970]

146. Krajewski S, Krajewska M, Reed JC. Immunohistochemical analysis of in vivo patterns of Bak expression, a proapoptotic member of the Bcl-2 protein family. Cancer Res. 1996; 56:2849-2855. [PubMed: 8665525]

147. Gaur U, Aggarwal BB. Regulation of proliferation, survival and apoptosis by members of the TNF superfamily. Biochem Pharmacol. 2003; 66:1403-1408. [PubMed: 14555214]

148. Filippova M, Parkhurst L, Duerksen-Hughes PJ. The human papillomavirus 16 E6 protein binds to Fas-associated death domain and protects cells from Fas-triggered apoptosis. J Biol Chem. 2004; 279:25729-25744. [PubMed: 15073179]

149. Filippova M, Song H, Connolly JL, Dermody TS, Duerksen-Hughes PJ. The human papillomavirus 16 E6 protein binds to tumor necrosis factor (TNF) R1 and protects cells from TNF-induced apoptosis. J Biol Chem. 2002; 277:21730-21739. [PubMed: 11934887]

150. Kabsch K, Alonso A. The human papillomavirus type 16 E5 protein impairs TRAIL- and FasLmediated apoptosis in HaCaT cells by different mechanisms. J Virol. 2002; 76:12162-12172. [PubMed: 12414956]

151. Thompson DA, Zacny V, Belinsky GS, Classon M, Jones DL, Schlegel R, Munger K. The HPV E7 oncoprotein inhibits tumor necrosis factor alpha-mediated apoptosis in normal human fibroblasts. Oncogene. 2001; 20:3629-3640. [PubMed: 11439326]

152. Garnett TO, Duerksen-Hughes PJ. Modulation of apoptosis by human papillomavirus (HPV) oncoproteins. Arch Virol. 2006; 151:2321-2335. [PubMed: 16862386]

153. Jackson S, Storey A. E6 proteins from diverse cutaneous HPV types inhibit apoptosis in response to UV damage. Oncogene. 2000; 19:592-598. [PubMed: 10698529]

154. Frisch SM, Ruoslahti E. Integrins and anoikis. Curr Opin Cell Biol. 1997; 9:701-706. [PubMed: 9330874]

155. Sastry SK, Horwitz AF. Adhesion-growth factor interactions during differentiation: an integrated biological response. Dev Biol. 1996; 180:455-467. [PubMed: 8954718]

156. Tong X, Howley PM. The bovine papillomavirus E6 oncoprotein interacts with paxillin and disrupts the actin cytoskeleton. Proc Natl Acad Sci USA. 1997; 94:4412-4417. [PubMed: 9114003]

157. Vande Pol SB, Brown MC, Turner CE. Association of bovine papillomavirus type 1 E6 oncoprotein with the focal adhesion protein paxillin through a conserved protein interaction motif. Oncogene. 1998; 16:43-52. [PubMed: 9467941]

158. Du M, Fan X, Hong E, Chen JJ. Interaction of oncogenic papillomavirus E6 proteins with fibulin-1. Biochem Biophys Res Commun. 2002; 296:962-969. [PubMed: 12200142] 
159. Degenhardt YY, Silverstein S. Interaction of zyxin, a focal adhesion protein, with the e6 protein from human papillomavirus type 6 results in its nuclear translocation. J Virol. 2001; 75:1179111802. [PubMed: 11689660]

160. Huh KW, DeMasi J, Ogawa H, Nakatani Y, Howley PM, Munger K. Association of the human papillomavirus type $16 \mathrm{E} 7$ oncoprotein with the $600-\mathrm{kDa}$ retinoblastoma protein-associated factor, p600. Proc Natl Acad Sci USA. 2005; 102:11492-11497. [PubMed: 16061792]

161. Massimi P, Gammoh N, Thomas M, Banks L. HPV E6 specifically targets different cellular pools of its PDZ domain-containing tumour suppressor substrates for proteasome-mediated degradation. Oncogene. 2004; 23:8033-8039. [PubMed: 15378012]

162. Tomaic V, Gardiol D, Massimi P, Ozbun M, Myers M, Banks L. Human and primate tumour viruses use PDZ binding as an evolutionarily conserved mechanism of targeting cell polarity regulators. Oncogene. 2009; 28:1-8. [PubMed: 18820705]

163. Kupper TS, Fuhlbrigge RC. Immune surveillance in the skin: mechanisms and clinical consequences. Nat Rev Immunol. 2004; 4:211-222. [PubMed: 15039758]

164. Tindle RW. Immune evasion in human papillomavirus-associated cervical cancer. Nat Rev Cancer. 2002; 2:59-65. [PubMed: 11902586]

165. Woodworth CD. HPV innate immunity. Front Biosci. 2002; 7:d2058-d2071. [PubMed: 12165480]

166. Chang YE, Laimins LA. Microarray analysis identifies interferon-inducible genes and Stat-1 as major transcriptional targets of human papillomavirus type 31. J Virol. 2000; 74:4174-4182. [PubMed: 10756030]

167. Ronco LV, Karpova AY, Vidal M, Howley PM. Human papillomavirus 16 E6 onco-protein binds to interferon regulatory factor-3 and inhibits its transcriptional activity. Genes Dev. 1998; 12:2061-2072. [PubMed: 9649509]

168. Li S, Labrecque S, Gauzzi MC, Cuddihy AR, Wong AH, Pellegrini S, Matlashewski GJ, Koromilas AE. The human papilloma virus (HPV)-18 E6 oncoprotein physically associates with Tyk2 and impairs Jak-STAT activation by interferon-alpha. Oncogene. 1999; 18:5727-5737. [PubMed: 10523853]

169. Barnard P, Payne E, McMillan NA. The human papillomavirus E7 protein is able to inhibit the antiviral and anti-growth functions of interferon-alpha. Virology. 2000; 277:411-419. [PubMed: 11080488]

170. Park JS, Kim EJ, Kwon HJ, Hwang ES, Namkoong SE, Um SJ. Inactivation of interferon regulatory factor-1 tumor suppressor protein by HPV E7 oncoprotein: implication for the E7mediated immune evasion mechanism in cervical carcinogenesis. J Biol Chem. 2000; 275:67646769. [PubMed: 10702232]

171. Perea SE, Massimi P, Banks L. Human papillomavirus type $16 \mathrm{E} 7$ impairs the activation of the interferon regulatory factor-1. Int J Mol Med. 2000; 5:661-666. [PubMed: 10812019]

172. Hebner CM, Wilson R, Rader J, Bidder M, Laimins LA. Human papillomaviruses target the double-stranded RNA protein kinase pathway. J Gen Virol. 2006; 87:3183-3193. [PubMed: 17030851]

173. Ashrafi GH, Haghshenas MR, Marchetti B, O’Brien PM, Campo MS. E5 protein of human papillomavirus type 16 selectively downregulates surface HLA class I. Int J Cancer. 2005; 113:276-283. [PubMed: 15386416] 


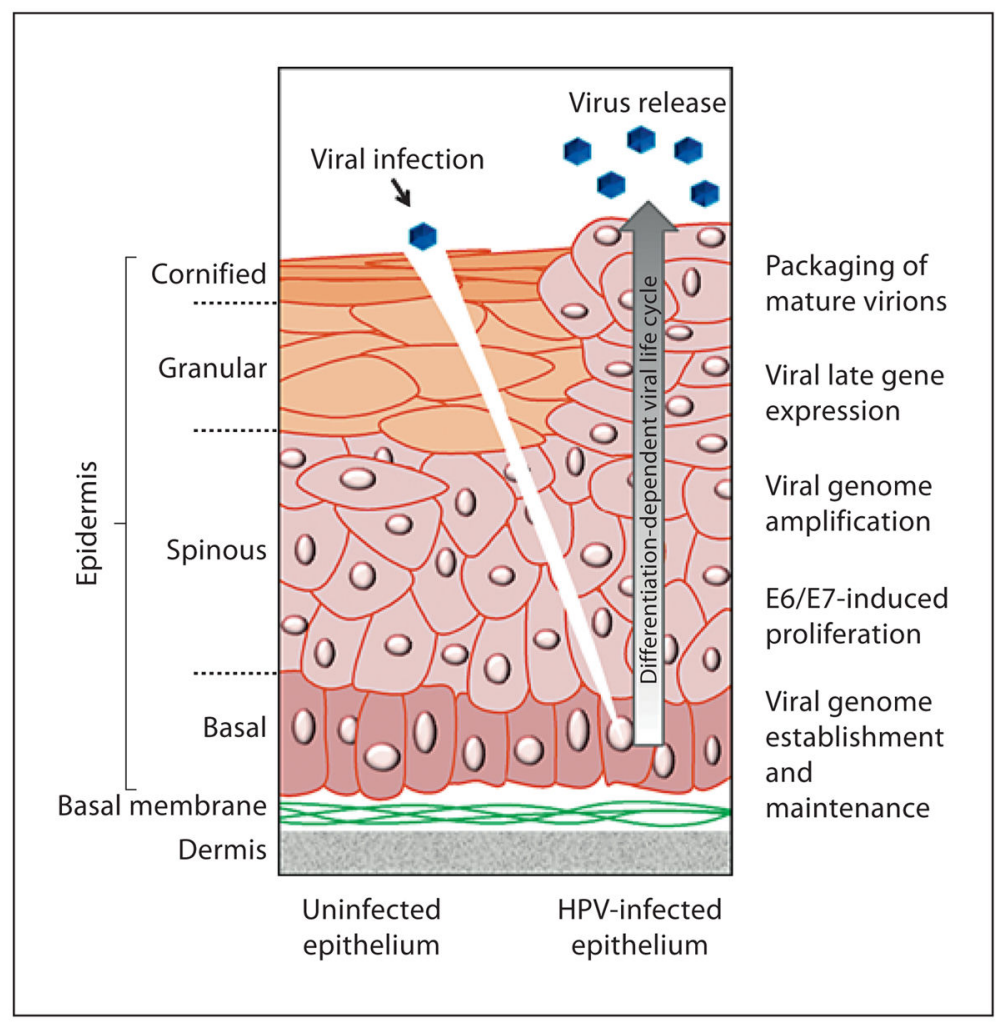

Fig. 1.

Schematic representation of the HPV life cycle in the context of a differentiating epithelium. Sections of normal uninfected (left) and HPV-infected epithelia (right) are represented in this illustration. The HPV life cycle is dependent on the differentiation program that keratinocytes undergo within a stratified epithelium. HPV virions infect dividing keratinocytes of the basal cell layer where they establish and maintain their genome as a low copy number episome in the nucleus of these cells. Although un-infected cells ultimately differentiate and lose their nuclei, expression of the viral oncogenes E6 and E7 prevents terminal differentiation of infected keratinocytes and keeps them in a proliferative state needed for viral DNA synthesis. As the cells migrate towards the upper layers of the epithelium, the viral genome is amplified and late gene expression is induced. Synthesis of the 2 capsid proteins allows for the viral DNA to be packaged into mature virions, which are then released from the top portion of the epithelium through natural shedding. The different cell layers of the epithelium and the viral events occurring within them are indicated on the left and right side of the figure, respectively. 


\section{Conserved regions}

12

ウ

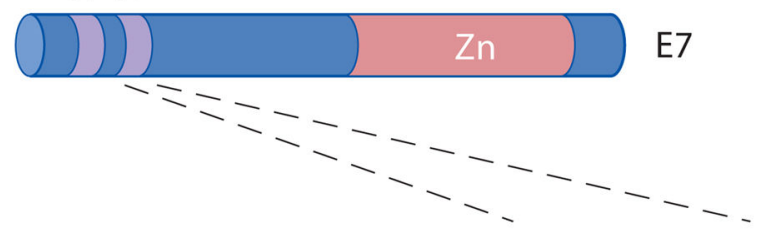

HPV16 27

TDLYCYEQL

HPV18 E7 VDLLCHEQL

Ad5 Ela IDLTCHEAG

SV40 large $\mathrm{T}$ ENLFCSEEM

a pRb-binding motif ..LXCXE..

PDZ

binding

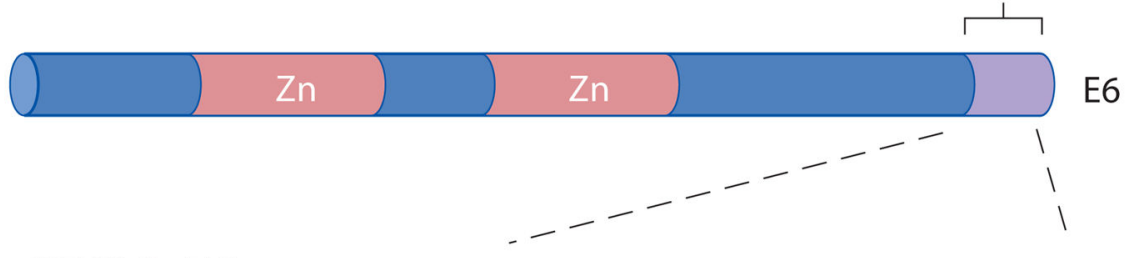

HPV16 E6

C.......RSSRTRRETQL

HPV18 E6

C . . CNRARQERLQRRRETQV

HPV6 E6

CWTTCMEDMLP........

HPV11 E6

CWTTCMEDLLP ........

b PDZ-binding motif $\ldots \ldots \ldots x_{S}^{T} x_{L}^{V}$

Fig. 2.

Schematic representation of the HPV oncoproteins E6 and E7. a E7 harbours 1 zinc finger $(\mathrm{Zn})$ in its $\mathrm{C}$-terminal domain and 2 amino-terminal conserved regions. Conserved region 2 contains the consensus sequence $\mathrm{LxCxE}$ required for $\mathrm{pRb}$ binding, and is highly conserved among HPV types, as well as in adenovirus type $5 \mathrm{E} 1 \mathrm{~A}$ protein (Ad5 E1A) and simian virus 40 large T antigen (SV40 large T). b E6 harbours 2 zinc finger domains. A C-terminal PDZbinding domain of the consensus sequence $\mathrm{x}-(\mathrm{T} / \mathrm{S})-\mathrm{x}-(\mathrm{V} / \mathrm{L})$ is also present in the E6 proteins from high-risk HPV types (HPVs 16 and 18), but is absent in their low-risk counterparts (HPVs 6 and 11). 


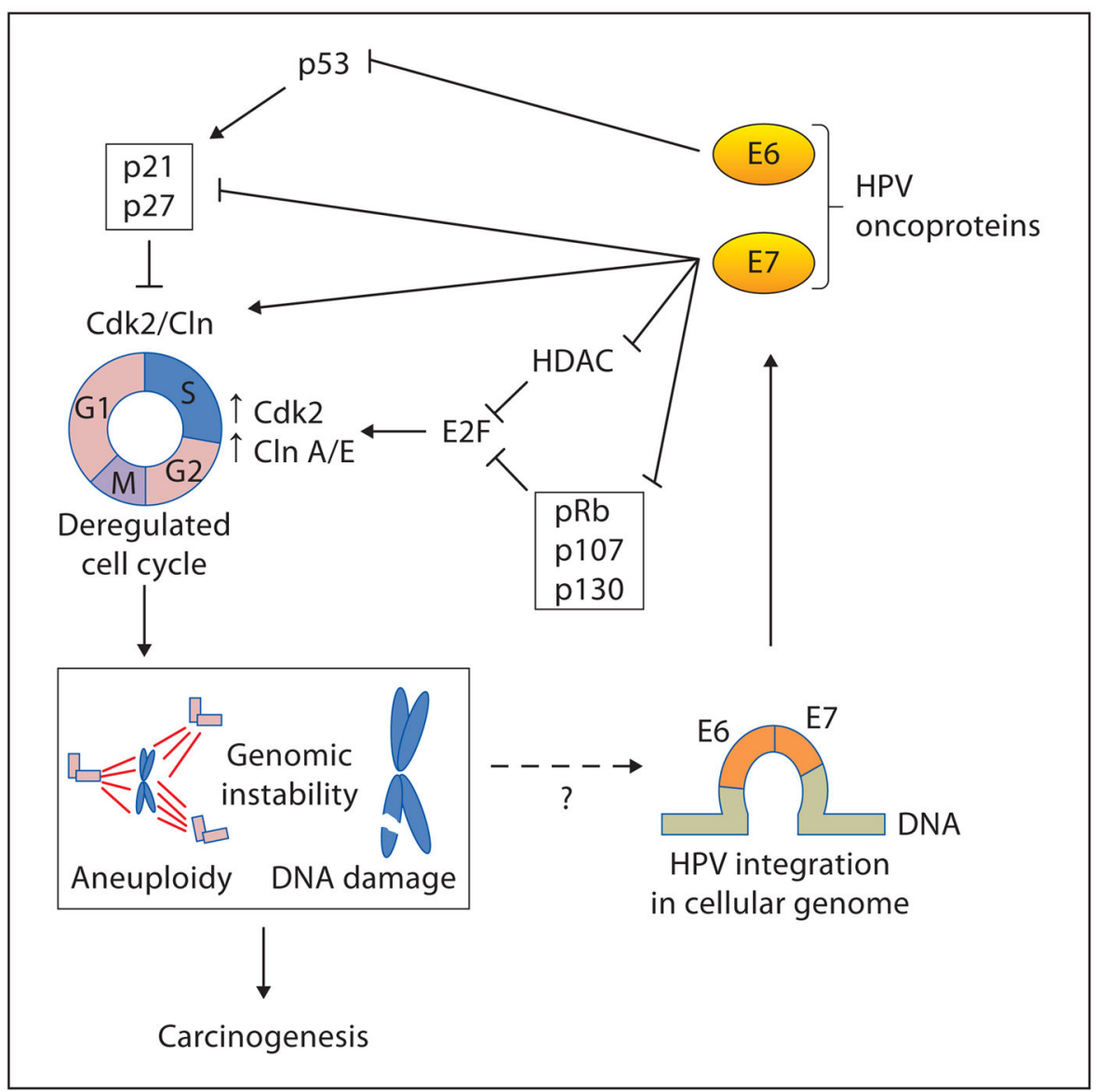

Fig. 3.

Molecular mechanisms of HPV-induced cellular proliferation and genomic instability. HPV E7 induces cellular proliferation by 4 main mechanisms that culminate in the activation of E2F and re-entry of cells into S-phase. These mechanisms involve: (1) inhibition and degradation of $\mathrm{pRb}$ and related pocket proteins p107 and p130; (2) stimulation of cyclinA/ECdk2 synthesis and activity; (3) inhibition of the Cdk2 inhibitors p21 and p27; (4) inhibition of specific histone deacetylases (HDAC) involved in E2F repression. E6 also contributes to cellular proliferation through its inhibition of $\mathrm{p} 53$, which results in decreased transcription of p21 and p27 and prevention of E7-induced apoptosis. These synergistic effects of E6 and E7 result in uncontrolled cell division and high genomic instability, possibly facilitating viral integration into the host genome. Integration events that disrupt the E2 open reading frame lead to an increase in E6 and E7 expression and associated genomic instability, a hallmark of cancerous cells. 


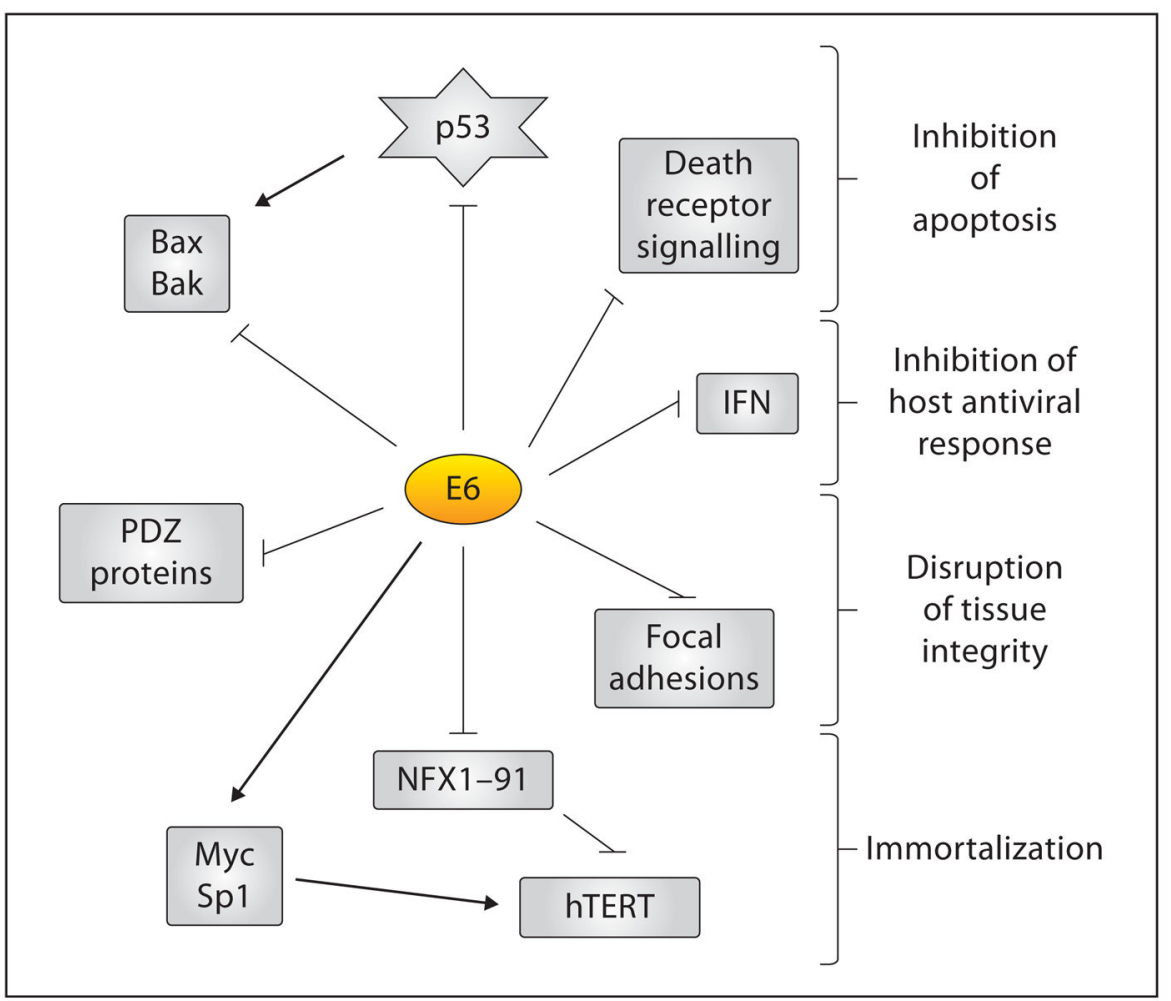

Fig. 4.

Cellular proteins and processes affected by the HPV E6 oncoprotein. E6 interacts with several cellular proteins involved in apoptosis, tissue integrity, telomerase regulation and IFN antiviral response. The primary anti-apoptotic function of E6 is to inhibit p53. E6 also interferes with other cellular proteins involved in intrinsic and extrinsic apoptotic pathways, including Bax, Bak and downstream effectors of death receptor signalling. Additionally, E6 contributes to the disruption of tissue integrity by binding to focal adhesion molecules and PDZ domain-containing proteins. E6 also helps HPV-induced cellular immortalization by its induction of the telomerase hTERT proceeding through transcriptional activation by Myc and Sp1, as well as by inhibition of the transcriptional repressor NFX1-91. Finally, E6 also inhibits the host IFN antiviral response. 